Для цитирования: Ginzburg Lydia. Looking at three years of ICPP // Социум и власть. 2021. № 3 (89). С. 78-82. DOI 10.22394/1996-0522-2021-3-78-82.

DOI 10.22394/1996-0522-2021-3-78-82

UDC 101.9

\section{LOOKING AT THREE YEARS OF ICPP}

\author{
Ginzburg Lydia, \\ Hebrew University of Jerusalem, \\ Ph.D candidate in Anthropology, \\ Mt. Scopus 9190501 Jerusalem, Israel \\ E-mail: lydia.ginzburg@gmail.com
}

Abstract

The article is an analytical and critical review of the main ideas of philosophical practice. The review was prepared on the basis of the author's personal participation in the work of international conferences on philosophical practice over the past three years. The comparison of the three last conferences reveals how tensions around definitions and goals of the practice have been reduced in ways that reflect an openness and appreciation of multiplicity. The anguish surrounding the boundaries of the field have decreased as well, and is seems that philosophical practice is ready to reflect on itself through the research, publication, networking and mapping.

Key words: philosophical practice, philosophical counselling, international conferences on philosophical practice, philosophical associations.
The coronavirus and its emerging mutations have brought dramatic changes to how we live and work. Our freedom of movement and social contact has become more restricted, and in ways that demand careful calculation. The pandemic has also affected International Conference of Philosophical Practice. While the tradition of conferences has indeed been reconfigured over the past two years (due to the coronavirus and the consequences it has brought) the pandemic is certainly not the only cause of change. The conferences evolve over the years, and in this short paper I would like to propose several directions of that evolvement. I will suggest that the conferences reflect major trends of philosophical practice around the world.

I study philosophical practice as an anthropologist, which means trying to understand how philosophical practitioners articulate their knowledge and praxis during ICCP gatherings. In this regard, my research is not very different from the more "traditional" form of anthropological research that has observed social gatherings and rituals of groups like the latmul of Papua New Guinea or Achuar in Amazonas. In many ways, international conferences are a kind of ritualistic gathering of philosophical practitioners from different parts of the world. Despite their cultural and social differences, participants share a common passion for philosophy and strive to practice it in a way available for wider population.

My interest in conducting fieldwork at ICPP conferences began in 2018, at the UNAM campus (National Autonomous University of Mexico) in Mexico City. The $15^{\text {th }}$ ICPP was organized by David Sumiacher and his colleagues. The conference panel discussions, lectures and numerous workshops and daily courses were complemented by many opportunities for participants to communicate informally during breaks, evening events, and a tour to the Teotihuacán pyramids that took place at the end of the conference. The warm atmosphere and collegiality of these conversations and events reflected at some workshops and lectures as well. But it contrasted with the rivalry and antagonism that arose during heated panel discussions and some lectures. At times, it seemed that no agreement could be reached on fundamental issues, such as defining what philosophical practice is and what its aims are, who is the founding figure or source of inspiration, and what the criteria for practice are $^{1}$. While participants were able to contain

${ }^{1}$ A more detailed discussion on the topic of disagreement during $15^{\text {th }}$ ICPP in Mexico-city can be found at https://philopractice.org/web/blog/an-anthropologistat-the-icpp-in-mexico. 
multiple differences between their approaches to philosophical practice, at other times some were accused of "not being philosophical (enough)", on applying psychological or religious approach or received questions such as "how is this philosophy"?

Perhaps this level of agon were due to the fact that for the first time in many years almost all of the "founding figures" of the movement were present, including Gerd Achenbach, Leon de-Haas, Ran Lahav and Lou Marinoff as well as many veterans and prominent figures of the movement such as Lydia Amir, Maria Tillmanns, Vaughana Feary, Ora Gruengard, Anders Lindseth, Peter Raabe and Oscar Brenifier (among others). Every one of these practitioners has developed her/his own particular approach and stressed its uniqueness, while, at times, criticizing the understandings and performances of philosophical practice that others have put forward.

The volume of disagreement was particularly salient compared to the subsequent 16-th ICPP held online in two parts in 2020 and 2021 and hosted by Sergei Borisov and his Russian colleagues. $^{1}$

With coronavirus entering our lives, sending many social activities to operate online the atmosphere of the conference had changed drastically. At the 2020 conference the ambiance was not just collegial - many participants expressed a thirst for social contact during their presentations. The conference held in 2020 was unusually large. It started with 396 registered participants from 44 countries, and finished with 500 participants from 52 countries spanning 5 continents. It was the largest conference by far, especially if we consider how the first ICPP held in 1994 included 92 participants, the 15-th in Mexico City included about 150 participants (most of whom from South and North America), and the 2021 online ICPP, which included 275 participants from 45 countries.

Not only did the atmosphere change during the 2020 conference, but it diminished rivalries. The conferences became larger and much more multi-national, and there were some substantial additional changes as well.

Firstly, it seems that in two parts of 16-th ICPP the question often asked during 15-th ICPP "how is this philosophy" was abandoned. During first panel discussion held in 2020, Leon de Haas has summed up his view by

\footnotetext{
${ }^{1}$ You can get acquainted with the program of conferences, abstracts of speeches, as well as watch video recordings of lectures, seminars and panel discussions on the conference website: https://www. icpp2020.ru/en/program-and-events.
}

saying: "Philosophy is multiplicity, as a global community we are very loose, and I am ok with this." Later, in his presentation he suggested in a similar vein that "everyone should create his or her own Socrates". In 2021, many other practitioners including Lydia Amir repeatedly argued that philosophy presupposes a plurality of views - this way ruling out attempts of delegitimizing attitude. But along with inclusiveness of approaches questions were raised, especially during 2020 conference, considering criteria of inclusion of practitioners into international movement. The suggested criterion of inclusion was personal dedication or compatibility as presented by Gerd Achenbach in his 2018 presentation, and by Lydia Amir and Alexandar Fatic during 2020 panel discussion, and not a formal qualification such as education.

The open and plural attitude was not the only novelty in the $16^{\text {th }}$ ICPP, I noticed that the exclusion of psychology had diminished. At panel discussion in 2020 participants raised suggestions to rethink relations between the two disciplines. Alexandar Fatic noted that psychology has its roots in philosophy and proposed to deal with transference and countertransference in a counselling relationship that is common to psychotherapy and philosophical counselling. Pia Houni asked "What is therapeutic in philosophical practice?" and Jörn Kroll sought to combine psychological and philosophical ideas and methods in his presentation, "The diamond approach: a psychodynamic epistemology of knowing." Offering another example of how the two disciplines not only intersect but can influence each other, Young Ki Kim's comparison of "Hip-hop philosophy" (drawing on Nietzsche's philosophy) was based on psychological "Rap therapy" by Don Elligan.

It seemed that psychology ceased being a taboo among philosophical practitioners, who started to ask questions about the differences and similarities between philosophical practice and psychotherapy. While some accepted the possibilities for interdisciplinary exchanges between philosophy and psychology, others problematized them. For example, Maria Tillmanns argued, "I am not against psychology, I am against psychologizing philosophy". Similarly, Leon de Haas argued for a difference between the roles of "counsellor" and "philosopher" in philosophical counselling.

During the opening lecture of the 2021 ICPP, Gerd Achenbach drew a line between philosophical practice on one hand and psychotherapy and academic philosophy on the other. Achenbach compared these two 
approaches to different floors of a house, using the following epigraph: "Psychoanalysts seclude themselves to the basement, transcendental philosophers lose themselves in the clouds, while a philosophy practitioner receives her guests in the mezzanine." Following the lecture, Neri Pollastri's presentation delineated the differences between his and Achenbach's approach by calling to "recognize the plurality of practices" and to cultivate and promote collaboration between practitioners applying different approaches.

Although this call to overcome differences had been raised previously, for example, by Jose Barrientos-Rastrojo's (2018 ICPP), during the both online parts of 16-th ICPP it was much more implemented in practice rather than sound in as a wish to be fulfilled during $15^{\text {th }}$ ICPP.

The need for a sharp distinction between philosophical practice and academic philosophy put forward by Achenbach was challenged by Leon de Haas and Lydia Amir in their lectures in 2020, who made the case for connecting philosophical practice with academic philosophy by linking the ideas and distinguishing the methods of both. The distinction has also dissolved de-facto during presentations of some Russian practitioners (for example Vladimir Klementyev in 2020 and Gulnara Shalagina in 2021).

By comparing the online format of the $16^{\text {th }}$ ICPP with the $15^{\text {th }}$ "in-person" conference, it seems that the international movement of philosophical practitioners has begun to overcome its "formation state anxiety" and feels less threatened by close fields (namely psychology and academic philosophy). This flexible and perhaps more "mature" approach paved way to questioning the interrelation between philosophical practice and these fields (especially psychology) instead of attempts to isolate the practice from their impact.

Moreover, in both 2020 and 2021 parts of the conference Jose Barrientos-Rastrojo called for cooperation between philosophical practitioners and academic institutions. In 2020, he said: "Now we have more university professors who are philosophical practitioners, we have more power, and it's our time to use it, to make research, to reform our lectures and classrooms." And in 2021 he argued: "We have to do research inside the academy, to be professors and associate professors. Today we don't have professors who can authorize a PhD on philosophical practice. Please be professors and do research in philosophical practice".

Since 2017, Jose Barrientos-Rastrojo and his associates have engaged in a project called BOECIO (BOETHIUS), which examines philosophical practice and research in prisons across Mexico, Argentine, Brazil, Colombia, Italy and Spain. The emphasis on research appeared in 2021 conference, where Michael Noah Weiss had organized a panel on philosophical practice and research, inviting Barrientos-Rastrojo, Anders Lindseth, Donata Romizi and Guro Hansen-Helskog (all of whom engage in research in different fields, such as education, counselling and methodology of ancient philosophy).

The research of the practice by practitioners themselves is not widespread, and this panel suggested that a conference can provide a basis for reflection on the practice as well as sharing the findings and experience of research. Yet, the research can have its' own impediments, as Donata Romizi had noticed at the panel discussion. There is a tension between philosophical practice and research methods, especially as scientific research demands clear criteria for the success of practice. To quote Romizi directly, "...if our aim is to have an open dialogue, how shall we study that"? The same problem can be posed by qualitative methods of research (like those applied in the BOECIO project) that can affect the practice itself. She suggested the main distinction to be the "disinterested interest" of research in philosophical practice that would not depend on utilitarian goals, although this disinterest may add difficulties for fund raising for the research.

The evolving nature of philosophical practice conferences did not start in 2018 , and can be traced as far back as the first conference in 1994. Yet some important changes regarding the networks between the practitioners have happened over the last twenty years. In 2009, Jose Barrientos-Rastrojo initiated Haser, an academic journal in English and Spanish, in order to create a space for practitioners and aspiring students in philosophical practice to publish their work. The academic standing of the journal has raised in recent years, offering an additional incentive to practitioners to use the journal as a platform for their networking. The journal was presented on every conference since ${ }^{1}$. Similarly, as the 2020 ICPP drew to a close, Lydia Amir announced that Lexington Press approached her with a proposal to publish series of books on philosophical practice. She stressed it's important to present all

${ }^{1}$ Since 2016 Russian academic journal "Society and Power" publishes articles on theoretical and methodological aspects in philosophical practice written by the most prominent members of the movement (in English and Russian). The journal includes overviews of ICPP-s since 2016 as well. 
the existing thoughts and approaches as a chance to leave some legacy of the pioneers for younger generation of philosophical practitioners.

The Internet has afforded practitioners with unlimited opportunities for networking and exchange. Although many local organizations have their own Internet sites, the need for an international site became apparent. In 2014, Ran Lahav and Carmen Zavala created The Philosophical Practice Agora site as a way to provide "a space for pluralistic dialogue among philosophical practitioners from around the world, as well as the general public". ${ }^{1}$

The site remains active to create dialogue between practitioners and ignite initial curiosity and interest in philosophical practice on behalf of general public. The scope of the site, however, was insufficient for a group of younger philosophical practitioners who participated in a vibrant workshop in the 2020 ICPP, called "Creating an international network for sharing of experience and cooperation on philosophical practice" organized by André de Almeida. The workshop focused on networking among practitioners from a business perspective, like Jorge Jose Dias proposed, "We have to learn how to make money from philosophy." The organizer suggested to discuss: "How to establish and run a successful practice", practice promotion and "positioning strategy that will add real value for the clients." He advised workshop participants to take a pragmatic approach by looking for "state of the art techniques" in different fields (like group counselling or philosophy with/for children) or to develop new approaches.

The ideas put forward in the workshop gave birth to the Philosophical Practice Hub Project, which was launched at the 2021 ICPP. The hub (a website) aims to provide information for practitioners as well as clients on different fields of philosophical practice including the bibliography. The site is under construction yet and it takes a very different route than Philosophical Practice Agora through its pragmatic approach, wider scope, its stress on connecting practitioners with clients and its division of philosophical practice into fields.

Two additional initiatives were announced at the 2021 conference, including a book Filosophia en Movimiento that will map diverse approaches and groups of philosophical practitioners functioning around the world along with the critiques that practitioners encounter. This project is led by Jose Barrientos-Rastrojo, who's joined by Paulina Ramirez and Tania Ortiz. One of the criticisms the project reveals ${ }^{1}$ You can get acquainted with the materials of the site here: https://philopractice.org/web. was a tendency to distance philosophical practice from political and social issues, an issue I have also observed. During the $15^{\text {th }}$ ICPP, political and social issues (such as living conditions of indigenous and rural communities as well as low-income urban neighborhoods, education level in these areas, prison inmates' conditions and education, awareness to social and political injustice) were widely raised by Walter Kohan, Eugenio Echeverría, Félix García Moriyón, Victoria Carasco, Vaughana Feary, Leon de Haas and Jose Barrientos-Rastrojo in a range of panels, lectures and workshops. It should be noted that political issues were consensual rather than controversial during the conference. Their number has dropped sharply during the $16^{\text {th }}$ conference, where only Barrientos-Rastrojo, Ora Gruengard, Carmen Zavala and Pia Houni (in 2020) raised broader (like role of politics in philosophical practice) or more specific social and political issues (inmates condition and education and questions of ethics). Perhaps future conferences will make it clear whether this drop was due to a general impact of the pandemic or an emerging trend of de-politicizing philosophical practice.

The last initiative presented at the closing of $16^{\text {th }}$ ICPP in 2021 was the site icpp.com, launched by Lou Marinoff and David Sumiacher, which preserves the history of international conferences since 1994 and collates programs, descriptions and pictures.

ICPP has definitely changed and evolved during the last 27 years. The comparison of the three last conferences, which I have offered, reveals how tensions around definitions and goals of the practice have been reduced in ways that reflect an openness and appreciation of multiplicity. The anguish surrounding the boundaries of the field have decreased as well, and is seems that philosophical practice is ready to reflect on itself through the research, publication, networking and mapping. 27 years is a young age, yet the members of international movement are actively trying to cherish and preserve its legacy - which I also trace in this review.

If the conference is a mirror of the movement of philosophical practice, will the forthcoming conference in Romania reflect how the distinctive features of philosophical practice from psychology have been erased as a more inclusive approach is pursued? Will it reflect practices' further incorporation into the world of Academy and at what cost? Will it reveal how philosophical practice is undergoing processes of professionalization, maybe becoming another self-help discipline? 
Which of these trends will be fulfilled or perhaps all of them are just border marks, and philosophical practice will continue to carve its unique path with more confidence than before? Only time will tell.
Для цитирования: Гинзбург Лидия (Ginzburg Lydia). ICPP (Международные конференции по философской практике) в течение трех лет //

Социум и власть. 2021. № 3 (89). С. 78-82. DOI 10.22394/1996-0522-2021-3-78-82.

DOI 10.22394/1996-0522-2021-3-78-82

УДК 101.9

\section{ICPP}

\section{(МЕЖДУНАРОДНЫЕ КОНФЕРЕНЦИИ ПО ФИЛОСОФСКОЙ ПРАКТИКЕ) В ТЕЧЕНИЕ ТРЕХ ЛЕТ ${ }^{1}$}

\section{Гинзбург Лидия (Ginzburg Lydia),}

Еврейский университет Иерусалима, кандидат Ph.D по антропологии, Mt. Scopus 9190501 Jerusalem, Israel E-mail: lydia.ginzburg@gmail.com

\section{Аннотация}

Статья представляет собой аналитический и критической обзор основных идей философской практики. Обзор подготовлен на основе личного участия автора в работе международных конференций по философской практике за последние три года. Сравнение трех последних конференций показывает уменьшение напряженности вокруг определения того, что есть философская практика, и каковы ее цели в пользу многообразия представлений. Сомнения по поводу границ применения философской практики также уменьшились, и кажется, что философская практика готова если не четко определиться, то размышлять о себе через исследования, публикации, создание сетевого взаимодействия и структурирования.

Ключевые понятия:

философская практика,

философское консультирование,

международные конференции по философской практике,

философские объединения.

${ }^{1}$ Перевод с англ. выполнен С. В. Борисовым. 